and genetic disease. These snapshots produce a very contemporary form of autobiography - the autogenography, perhaps.

What she learns affects her ideas about herself and her children. From an apartment window in Moscow, she watches her adopted 9-year-old son drinking beer with a stranger in a park and reflects on the "dangerous business" of applying theories of genetic drift to humans when so much of how we are shaped is environmental. Is her son drawn to alcohol consumption from an early age by imitation or by genetic orientation? Like many commentators on the new genetics, Gessen is struck by the proliferation of genetic explanations in everyday life. She coins the term 'biobabble', after psychobabble, to describe how the gene is overused as a justification, such as when "midcareer professionals start explaining to potential partners that they had never formed an intimate relationship because of this or that polymorphism".

Despite its futuristic subtitle, and the novelty of increasing 'genetic choice' as a result of developments in gene testing, the somewhat unexpected lesson from Gessen's book is that the difficulties associated with genetic futures are not so new. They are being solved with the same combination of heart and mind that is one of the defining characteristics of being human, she finds. An unfortunate absence in Gessen's account is the scholarly contribution from social science or social psychology, such as in Theresa Marteau's and Martin Richards's landmark book The Troubled Helix (Cambridge University Press, 1999), which also illustrates this point. Here, and in the wide literature providing qualitative analysis of the genetic knowledge gap that separates abstract scientific facts from actual human experience, Gessen would find that the active and engaged community she describes in Blood Matters is even larger than she thinks.

Sarah Franklin is associate director of the BIOS Centre at the London School of Economics and Political Science, Houghton Street, London WC2A $2 \mathrm{AE}, \mathrm{UK}$. She is author of Born and Made: An Ethnography of Preimplantation Genetic Diagnosis.

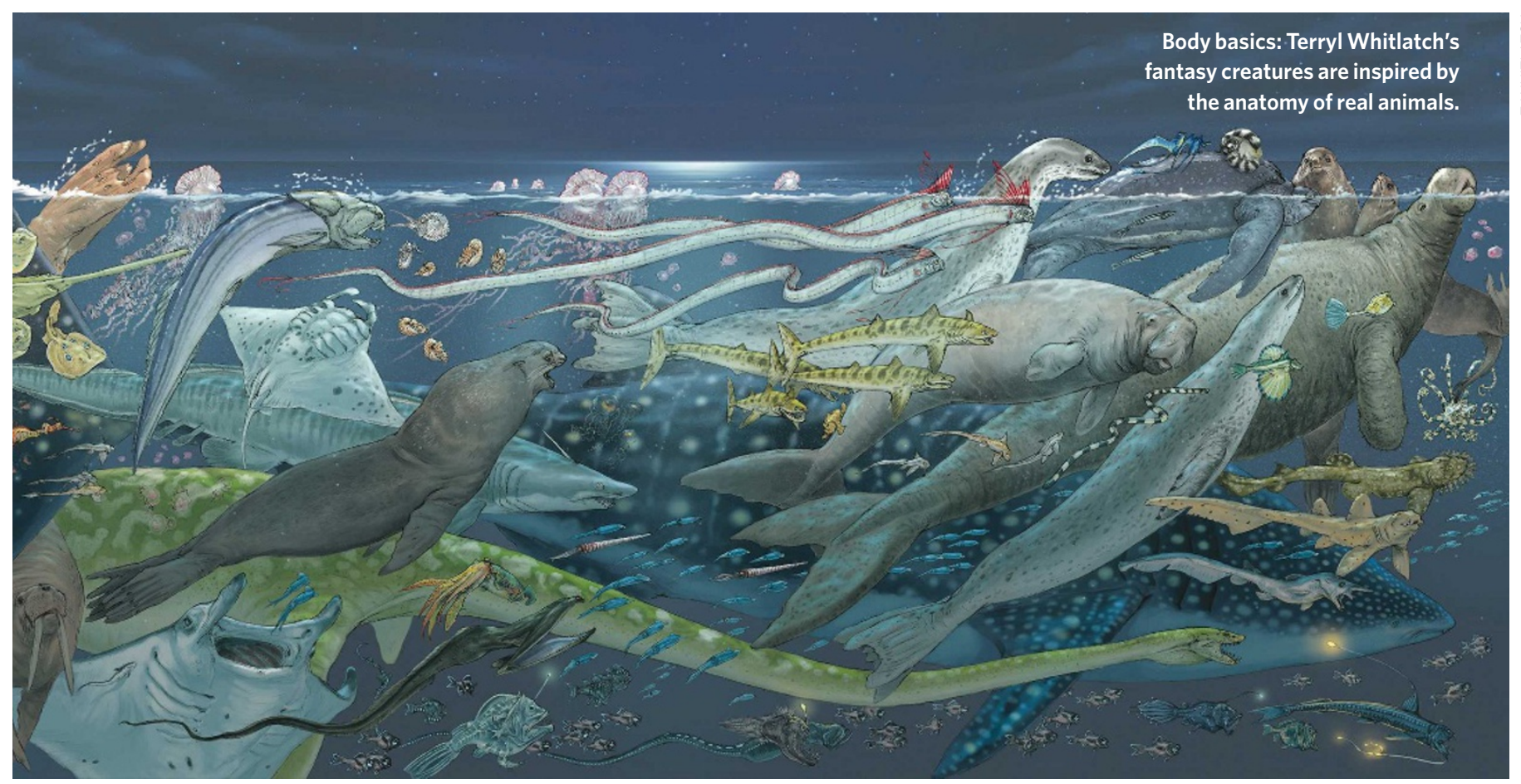

\section{Science artists draw together}

\author{
Annual Meeting of the Guild of Natural \\ Science Illustrators \\ Ithaca College, Ithaca, New York \\ 20-26 July. See www.gnsi.org
}

Science illustrators are in demand. Artists create images for books, posters and museum displays. In the film industry, talented concept artists design animals and fantasy creatures.

Forty years ago, the first meeting of the Guild of Natural Science Illustrators at the Smithsonian Institution, Washington DC, drew only a handful of local participants. The guild now has almost 1,000 members and, next week, hundreds will converge on Ithaca, New York, for the 2008 conference. Through workshops, lectures and field trips, "traditional artists using pencil, crowquill pens, and watercolour will come together with those on the edge of the latest computer software doing reconstructions and 3D animations", says Gretchen Halpert, the guild's president.

Terryl Whitlatch, a speaker at this year's conference, used her zoology training to design the monkeys and zebras for the 1995 fantasy film Jumanji. Her initial images were based on realistic skeletal, muscle and surface anatomy features that were then transformed into the three-dimensional computer-generated images seen in the film.

Whitlatch went on to invent alien creatures for the 1999 film Star Wars Episode I: The Phantom Menace. "I took ideas from animals and incorporated them into the world of fantasy art," she says. "I make sure the anatomy of a creature is matched with its environment to make it believable." The character of Jar Jar Binks, which was almost entirely computer generated for the film, was based on Whitlatch's combination of the duck-billed dinosaur, or hadrosaur, a frog, a parrot fish for skin patterns and markings, and an emu for the character's walk and stance.

Whitlatch creates her art with traditional techniques, then scans the artwork and enhances it 
with computer software. "The computer can't do it all for you," she says. "It's still just a tool like pencil and paper."

Keynote speaker Warren D. Allmon is not an artist, but an invertebrate palaeontologist. Scientific illustrators are "especially important in palaeontology, which is a mixture of science, inspired guesses, and artistic creativity to form a picture of what animals may have once looked like". The images can also help kids to think about how scientists do palaeontology, he explains. Reconstructing ancient worlds will be the focus of another keynote speaker, James Gurney, author and illustrator of Dinotopia: A Land Apart From Time (HarperCollins, 1992) and the artist behind the World of Dinosaurs series of US postage stamps.

Science illustrators claim that the origin of their craft dates back to prehistoric cave drawings. Medieval physicians, alchemists, naturalists and early scientists - including Newton and Galileo - used etchings and engravings to supplement their manuscripts. One of the best examples is Robert Hooke's Micrographia. Published in 1665, it introduced readers to the microscopic world through its detailed drawings.

"Historically, most illustrators have worked in isolation," adds Halpert. "The formation of the guild helped us learn what others were doing. What many think of as disparate vocations [science and art] have always been two sides of the coin."

Nick Thomas is an associate professor of chemistry at Auburn University Montgomery,

Alabama 36124-4023, USA.

\section{Climate comedy falls flat}

\section{Sizzle}

Premieres 19 July at Outfest Film Festival, California; screens on 26 July at Woods Hole Film Festival, Massachusetts. Showing at US universities thereafter.

After watching Al Gore's straight-faced presentation in the 2006 film An Inconvenient Truth, director Randy Olson turned to humour to tackle the issue of climate change. "I really liked it," he says of Gore's documentary in the opening to Sizzle, Olson's new film that premieres in Hollywood on 19 July, "but I kept thinking 'where are all the scientists?"

Part documentary, part mockumentary, Sizzle follows Olson as he interviews scientists and sceptics from around the United States with the help of a crew of thinly drawn comedic characters. Director of the well-received 2006 documentary on intelligent design, Flock of Dodos, Olson is no stranger to portraying society's complex response to science. Sadly, Sizzle's mix of styles confuses his message.

The interviewees, including researchers such as Gerald Meehl at the National Center for Atmospheric Research in Colorado and Richard Somerville at the Scripps Institution of Oceanography in California, look as if they think they are being interviewed for a straight documentary. Then Olson's cameraman, a climate-change sceptic played by comedian Alex Thomas in a solid and funny performance, butts in with his own contribution, a running gag that the film turns into a point about scientific communication: when you ask dumb questions in everyday language, scientists suddenly start talking like 'normal' people.

Olson argues that data alone fail to convince people to care about climate change. What succeeds is anecdote and emotion. Indeed, the film contains very little data. The interviews are edited down to mere stubs, with no explanation of what climate change is or why we should laugh at the sceptics. Perhaps Olson assumes his audience has previous knowledge.

Olson heads to New Orleans in search of compelling anecdotes. With the caveat that the relationship between climate change and hurricanes is still being worked out, he argues like many before him, including Gore, that Hurricane Katrina is a window into a climate-changed world - even the richest nation on Earth disintegrates into anarchy in the face of terrible natural disasters. But once he gets there, Olson wanders off-topic, preferring to criticize the federal response to the hurricane.

The film is good in places and provides insights into the social response to climate change. But some of the mockumentary's jokes, meant to keep us watching, are rather stale: an elderly white woman - Olson's mother - goes out on the town with the young black camera crew, and the gay film producers throw several colourful hissy fits.

Ultimately, one is left wondering what the film aims to do. Does it argue that climate change is real, or discuss how we might convince people that it is? At the end of the film, Olson heads off to the editing studio to make a coherent story out of his footage. If only we had got to see that version.

Emma Marris is a correspondent for Nature.

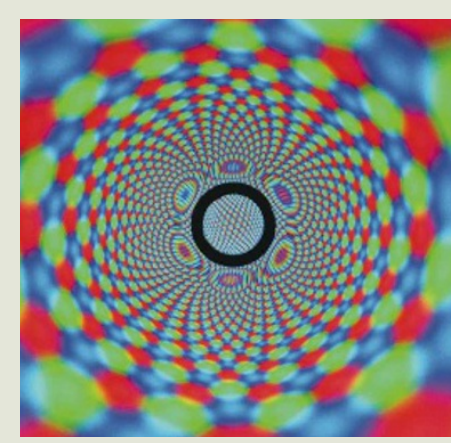

AND THE WINNER IS...

The winners of the Niche Prize, a competition held by the Royal Institution of Great Britain in partnership with Nature, have been announced. The winning works will be displayed in two wall niches on the ground floor of the institution in London, which reopens to the public in August. The Malaria Lifecycle (detail, below), by Australian visual designer Drew Berry, is a scientifically accurate animation of the malaria parasite invading a human host. Faraday's Magnetoscape (above) by Ken Skeldon, a research fellow at the University of Glasgow, UK, allows viewers to generate colour patterns by passing a magnet near the screen of a cathode-ray-style computer monitor, celebrating Michael Faraday's discovery of electromagnetic induction at the Royal Institution some 180 years ago.
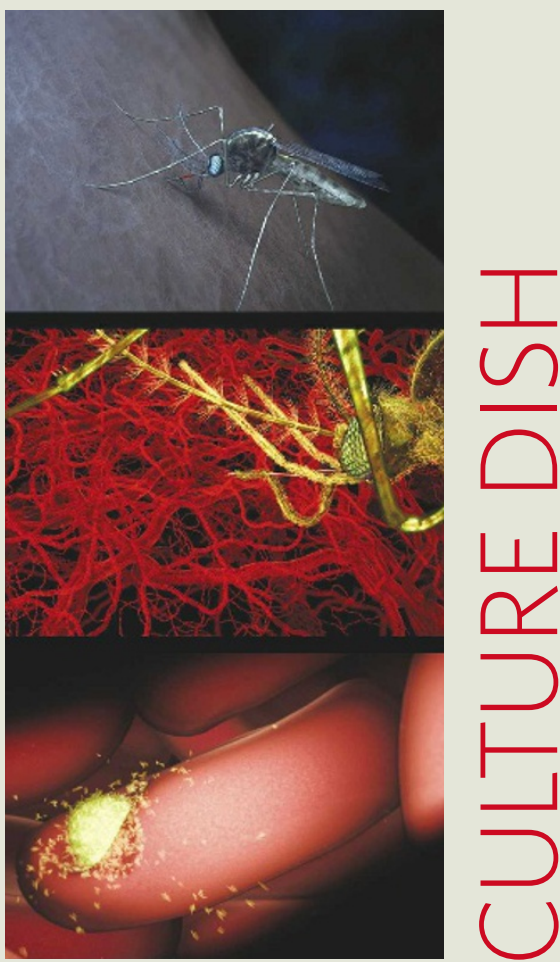